\title{
The Evolution of Intellectual Property Protection in China
}

\author{
Lu Chen \\ School of Management, Jinan University, Guangzhou, China \\ Email: smallpiglulu@126.com
}

Received 23 February 2015; accepted 15 March 2015; published 17 March 2015

Copyright (C) 2015 by author and Scientific Research Publishing Inc.

This work is licensed under the Creative Commons Attribution International License (CC BY). http://creativecommons.org/licenses/by/4.0/

(c) (i) Open Access

\begin{abstract}
This paper developed an in-depth understanding of China's IPP strategies, regulations, and implementation, collected and analyzed China's policy documents, laws, statistics and reports relevant to IPP, and reviewed the IPP evolution from 1970s to 2010s. Then we introduced four main enforcement options in China. At last, we evaluated the IPP level of China based on Park's method from 1985-2012. The quantitative result shows that the strength of IPP in China is growing year by year, and has reached a level close to developed countries.
\end{abstract}

Keywords

Intellectual Property Protection, Evolution, Assessment, China

\section{Introduction}

The intellectual property protection (IPP) in China aroused heated discussion among people all around the world. Intellectual property owners around the world have long complained about the inefficacy of intellectual property protection in China and have gone so far as to accuse the Chinese government.

It is questionable that why Chinese people are resistant to the concept of IPP? Is that correct? Will it change ever time ${ }^{1}$ This paper gives a descriptive review and assessment of China's intellectual property policies, in particular relating to implementation.

China is often criticized by its poor record in the protection of IP rights [1]-[4]. However, an examination of China's IP laws and the international treaties it has acceded to would put China at more developed economies.

Effective protection of intellectual property rights depends on both the existence of IP laws and the enforce-

${ }^{1}$ Am. Chamber of commerce in the P.R.C., Am. Chamber of commerce in Shanghai \& Am. Chamber of commerce in S. China, 2008 White Paper: American Business in China. pp. 55 fig. 24 (2008) [hereinafter White Paper], available at http://web.resource.amchamchina.org/wysiwyg/WP2008-PartI.pdf (follow "Part One: The Business Climate for American Firms in China” hyperlink). 
ment of the laws. Although much has been written about the IP rules and laws [5] [6], there is little empirical evidence of the importance of the enforcement. One reason is that studies of IP protection are generally performed at country level.

Country level analysis does not allow researchers to separate the confounding effect of the existence of IP laws and the effectiveness of enforcement. Unlike dealing with cross country variations in IP laws, Ang, Cheng and $\mathrm{Wu}$ analyzed the impact of the local enforcement of IP laws on financing of and investing in R \& D by firms in provinces throughout China [7]. They found that enforcement in the protection of intellectual properties did matter in China. High tech firms in provinces with better IP rights enforcement have greater access to external debt (formal and informal).

The rest of this paper proceeds as follows: Section 2 traces the development of IPP in China from 1970s to 2010s; Section 3 represents four main enforcement options in China; Section 4 measures the IPP of China from 1985-2010 based on the method of Park (2008); Section 5 makes a short conclusion.

\section{The Four Periods of IP "Hot Waves" in China}

The rush establishment and rapid development of the Chinese IP system is strongly related to the four periods of IP "hot waves" in China [8] [9]. Initially, during the negotiations of the Sino-US Trade Agreement and the SinoUS High Energy Physics Agreement, IP became an objectionable issue and negotiations reached an impasse. The US negotiators believed that IPP should be an integral part of bilateral agreements in science, technology and trade, as negotiators would be only allowed to sign an agreement on the condition of adequate IPP required by the US president.

The process of development of IPP in China is quite tortuous. What follow in this part are the four period of IP wave and the revolution of the IPP in China from 1973-2014.

\subsection{The First "IP Fever" (1979)}

The Chinese government had little knowledge and experience about the IP clauses in the early days; therefore, they were very laith to sign the agreements with US. This period has been described as the first "IP fever" because it was the start point of China to conduct very intensive research in this special area [9]. The current authors name this as the first "hot wave" on IP in China-the formation wave.

\section{3, Premier Minister Zhou's visit to WIPO}

In 1973, the approval of Premier Zhou Enlai and the China Council For The Promotion Of International Trade (CCPIT)'s Director of Legal Affairs visited WIPO. It was the first time that the Chinese government allowed an officer to visit an international intellectual property institution since the foundation of the state.

\section{4, the first formal activity of IPR}

The first formal activity of international intellectual property of China occurred in 1974 when the governments of China and Australia signed an exchange of notes regard the registration of trademark between both nations.

\section{Agreement}

Intellectual property rights (IPRs) have been acknowledged and protected in the People's Republic of China since 1979. The Agreement on Trade Relations Between the United States of America and the People's Republic of China of 1979 (“1979 Agreement”) was the starts of intellectual property protection by Western.

1980, access of WIPO

China joined WIPO as its 90rd member in 1980. Only one year after the acceding to WIPO, in 1981, the Director of WIPO Dr. Arpad Bogsch visited China, convened the first patent agents course personally at the CCPIT Headquarters in Beijing.

\section{4, the first patent law}

In March 1984, China's National People's Congress promulgated the first Chinese patent law, which is an epoch-making event which opened a new chapter of the protection of intellectual property rights.

1985, SIPO's foundation

The State Intellectual Property Office of the People's Republic of China (SIPO), also known as the Chinese Patent Office, is the patent office of the People's Republic of China (PRC). It was founded on 1980, as the Patent Office of the People's Republic of China, the predecessor of SIPO'2. It is responsible "for patent work and 
comprehensively coordination of the foreign related affairs in the field of intellectual property”3.

1989, joined the Madrid Agreement Concerning the International Registration of Marks

China joined the Madrid Agreement Concerning the International Registration of Marks in $1989^{4}$ the Madrid Agreement Concerning the International Registration of Marks, which dates from 1891, and the Protocol Relating to the Madrid Agreement, which was adopted in 1989, entered into force on December 1, 1995, and came into operation on April 1, 1996. Common Regulations under the Agreement and Protocol also came into force on that date.

\subsection{The Second Hot Wave (1991-1994)}

\section{2, Signed MOU with US}

Urged by American business executives, the USTR placed China on the "Priority Watch List" in 1989. By doing so, the United States gained leverage in negotiations with China while it did not need to initiate a Section 301 investigation.

In response to the Priority Watch List designation, China passed a new copyright law ${ }^{5}$ and issued new implementing regulations in 1990. A separate set of computer software regulations ${ }^{6}$ followed in 1991.

Hours before the deadline for imposing sanctions, both countries averted a potential trade war by signing the Memorandum of Understanding Between China and the United States on the Protection of Intellectual Property (“1992 MOU”).

\subsection{The Third Hot Wave-The Improvement Wave}

The third hot wave of IP occurred in 1995 when China became the signatory countries to the TRIPS agreement- “the improvement wave". The third wave reflected a very different picture of IP in China. In the first two waves, China was mainly influenced by the US under its one-sided threats and the treaties and conventions of WIPO. Nevertheless, in the third wave, one-sided threats have been confined under the WTO agreement. TRIPS became the most important measurement on international trade and IP.

1995, agreement between China and United States

The 1995 National Trade Estimate Report estimated that U.S. industries suffered almost \$850 million in losses due to copyright theft alone. On June 30 1994, the USTR again designated China a Priority Foreign Country and immediately initiated a Special 301 investigation. According to the Xinhua News Agency, China's international news service, China needed to take such retaliatory measures "to protect its sovereignty and national dignity."7 Ending up with the signing of “1995 Agreement”.

\subsection{The Forth Hot Wave-The Enforcement Wave}

The fourth wave-the enforcement wave, appeared in 2001 when China access into the WTO after 15 years of consultations. The principal character of this period has been the enhancement of legal enforcement.

\section{1, access of WTO, TRIPs}

In order to gain the access to WTO, China enhanced the protection of IPRs by designing a number of strategies in 1996 APEC Individual Action Plan, including improve the enforcement of administration, enhance the public awareness of IPRs protection and strengthen judicial tools [2].

Finally, China has gained the entry into the WTO in 2001, complying with the minimum standards of the Agreement on Trade-Related Aspects of Intellectual Property Rights (TRIPs). The TRIPs requires a number of countries to strengthen their patent and other intellectual property rights (IPR) systems. Even though policy makers have committed to significant reforms, the implementation of this agreement remains contentious.

\section{4, SIPO's progress}

In 2004, China has become the fourth largest patent office in number of patent filings in the world, the top

\footnotetext{
${ }^{3}$ http://www.sipo.gov.cn, Responsibilities of the State Intellectual Property Office of the People's Republic of China (SIPO), 2002-04-27. Consulted on April 26, 2007.

${ }^{4}$ See, e.g., WIPO, Status of Madrid Agreement Concerning the International Registration of Marks (July. 15, 2009).

${ }^{5}$ Copyright Law of the People’s Republic of China 1990, translated in2 China L. Foreign Bus. (CCH) ๆ11-700 (1993) [hereinafter Copyright Law]

${ }^{6}$ Computer Software Protection Rules 1991, translated in 2 China L. Foreign Bus. (CCH) ๆ 11-704 (1993).

${ }^{7}$ Hamilton,U.S. to Hit China with Stiff Tariffs, supranote 77, at A1.
} 
three countries are, by rank, Japan, the United States, and South Korea ${ }^{2}$.

\section{4, the Beijing WIPO office}

To improve cooperation on protection of intellectual property rights (IPR), the WIPO Director-General Francis Gurry came to Beijing in July for opening a WIPO office ${ }^{8}$, one of only four globally. Gurry spoke highly of China's support for WIPO, the high importance China attached to innovation and IPR protection and the remarkable achievements it made.

\section{4, the new strategy}

The Promotion Plan for the Implementation of the National Intellectual Property Strategy in 2014 was published on May $5^{\text {th }}$. This plan is promulgated to implement the requirements of the 18th National Congress of the Communist Party of China (CPC) and the 3rd Plenary Session of the 18th CPC Central Committee, carry out the requirements of the national television and telephone conference on implementing intellectual property strategy, promote the deep and efficient implementation of the national intellectual property strategy, identify the primary goals and measures for the implementation of the strategy in $2014^{9}$.

\section{The Enforcement of IPP in China}

The registered intellectual property rights available are invention patents, utility patents, design patents and trade-marks. Copyright can also be recorded ${ }^{10}$. There are four main enforcement options in China [8]:

\subsection{Administrative Actions}

The key Chinese administrative bodies are the Intellectual Property Offices (IPOs), the Administrations for Industry and Commerce (AICs), the Copyright Office, and the Quality and Technical Supervision Bureaus (QTSBs) (local divisions of the Administration for Quality Supervision Inspection and Quarantine). These are empowered to take certain actions against companies infringing intellectual property rights. These bodies between them have the power to:

- Raid defendants' premises and to seize and destroy infringing items;

- Impose injunctions to force the infringing party to desist;

- Levy fines on the infringing party for TM infringement, copyright infringement and counterfeiting patent certificates.

\subsection{Civil Litigation}

Civil litigation is equivalent to a court case. The usual remedies sought are injunctions, damages, delivery up and destruction (of tools/products). A civil action will generally take six to 12 months from the issuance of proceedings until handing down of the judgment. Infringing acts under Chinese Patent law include sale, offer for sale, use, manufacture and export. It is usually easiest to obtain evidence of sale or offer for sale, but even this is not entirely straightforward because Chinese courts require this type of evidence of infringement to be given by a notary public.

\subsection{Criminal Sanctions}

Criminal sanctions are only used in relation to patents where the counterfeiting of the patent certificates themselves has taken place. Such actions are rare; criminal proceedings are more common in relation to trade mark and copyright infringements. There are three methods of bringing criminal sanctions:

- IP owner reports to the Public Security Bureau (PSB);

- An administrative agency transfers its case to a criminal agency when it comes to suspect the damage inflicted by the defendant exceeds certain thresholds;

- A trade mark owner can choose to file a criminal lawsuit with the court known as a private prosecution.

The first two approaches are common whilst the final approach is less so because claimants have no compulsory powers to obtain evidence, unlike the authorities.

\footnotetext{
${ }^{8}$ http://news.xinhuanet.com/english/china/2014-07/11/c_133477844.htm

${ }^{9}$ http://english.sipo.gov.cn/laws/developing/201405/t20140505 944778.html

${ }^{10}$ China IPR SME Helpdesk. (2013) Enforcement of Intellectual Property Rights in China:

http://www.wipo.int/sme/en/best_practices/china_sme helpdesk.html
} 


\subsection{Using Customs to Halt Exports and Gather Evidence}

While practice varies across China, many Chinese customs authorities will proactively enforce trademarks registered with them. However, generally they will not do the same for patents nor copyright and therefore patent/ copyright owners wishing to have infringing goods seized by customs must inform the customs officers of the precise details of each shipment to be seized (including the container number). In practice, obtaining this information entails extensive use of private investigators.

\section{The Measurement of IPP of China Based on the Method of G. Park}

There are a lot of studies on patent systems, but only few of them have measured the overall strength of the system in each country [10]-[12]. The few available studies are based either on a "dummy variables" approach or on surveys of firms. Examples of the 'dummy variables' approach are Bosworth [13] and Ferrantino [14]. Their approach is to develop various indicators of whether certain features of patent laws exist.

They do not provide an integrated index of those indicators. Rapp and Rozek [15] aggregate their indicators (which too are dummy variables: 1 if a feature exists, 0 otherwise). The survey of Mansfield [16] is a typical example by using Rapp's approach, which samples the views of 94 U.S. multinationals of patent rights in 16 countries during 1991.

Ginarte and Park [17] present an index of patent rights for 110 countries for the period 1960-1990. The index differs greatly from previous measures in a number of ways for three reasons. First, it provides information about national patent rights for more countries and periods than do the surveys, which otherwise offer many insights. Secondly, broader categories of the patent system are considered, particularly the treatment of foreigners. Thirdly, the measures obtained in the dummy variable approaches exhibit little variability across countries. Park [18] has updated the index of patent rights to the year 2005 and included more countries (such as China and the East European countries, which were originally excluded because laws protecting industrial property were either non-existent or based on a different system, such as inventor certificates).

Five categories of the patent laws were examined: 1) extent of coverage; 2) membership in international patent agreements; 3) provisions for loss of protection; 4) enforcement mechanisms; and 5) duration of protection. [5] Each of these categories (per country, per time period) was scored a value ranging from 0 to 1 , as discussed below. The unweighted sum of these five values constitutes the overall value of the patent rights index.

What follows in this part are the measurement of IPP in China from 1985 to 2010 for easy comparison with Park's result ${ }^{11}$.

\subsection{Coverage}

The value of this category indicates the fraction of 8 elements (pharmaceuticals; chemicals; food; surgical products; microorganisms; utility models; software; plant and animal) that were specified as being patentable in the law or not.

As the government revised the patent law in 1992, plants and animals are excluded from the scope of patentable subject matters under the patent law of China since Jan. $1^{\text {st }}, 1993$ (Article 25) ${ }^{12}$.

So the value of "Coverage" is 1 from 1985 to 1992, and it is 0.875 since 1993.

\subsection{Membership in International Treaties}

Countries which are signatories to all 5 international agreements receive a value of 1 in this category, those which are signatories to just one receive a value of $1 / 5$. Table 1 shows the join time and the effective time of each treaty of China.

The Paris convention and revisions is one of the most early comprehensive international treaty which have the most extensive memberships, and it's the most basic and significant global multilateral international conventions in today's world as well.

The main objective of the Patent cooperation treaty is to coordinate and simplify the administrative procedures, helps patent Offices with their patent granting decisions, and facilitates public access to a wealth of technical information relating to those inventions.

\footnotetext{
${ }^{11}$ The IP index of China is “0” until 1985 for there exist no laws or regulations concerning about IPR.

${ }^{12}$ Patent Law of the People’s Republic of China (1985, 1992, 2000, 2008)
} 
Table 1. The effective time of each treaty of China.

\begin{tabular}{lcc}
\hline Treaty & Join time & Effective time \\
\hline Paris convention and revisions & $12 / 19 / 1984$ & $3 / 19 / 1985$ \\
Patent cooperation treaty & $1 / 1 / 1994$ & $1 / 1 / 1994$ \\
UPOV Convention & $3 / 23 / 1999$ & $4 / 23 / 1999$ \\
Budapest Treaty & $4 / 1 / 1995$ & $7 / 1 / 1995$ \\
TRIPS & $12 / 11 / 2001$ & $12 / 11 / 2001$ \\
\hline
\end{tabular}

Source: World Intellectual Property Organization (WIPO) ${ }^{13}$.

The International Union for the Protection of New Varieties of Plants (UPOV) is an intergovernmental organization which was established by the International Convention for the Protection of New Varieties of Plants, with the mission of providing and promoting an effective system of plant variety protection.

The Budapest treaty allows "deposits of microorganisms at an international depositary authority to be recognized for the purposes of patent procedure”.

The Agreement on Trade-Related Aspects of Intellectual Property Rights (TRIPS) is an international agreement administered by the WTO that sets down minimum standards for many forms of intellectual property regulation as applied to nationals of other WTO Members.

As is shown in Table 1, it can be concluded that the value of "Membership in international treaties" is " 0.2 " from 1985 to 1993, “0.4” in 1994, 0.6 from 1995 to 1998, “0.8” in 1999 and 2000, and it has reached the full mark “ 1 ” since 2001.

\subsection{Restrictions on Patent Rights}

Patent holders may also face risks of losing their patent rights. This category measures protection against losses arising from three sources: working requirements; compulsory licensing; and revocation of patents. A country that protects against all three sources receives a value of 1 in this category.

\subsubsection{Working Requirements}

Working requirements refer to the utilization of inventions, if a country doesn't require working at any point during the patent term, it receives a value of $1 / 3$.

Under Article 22 of the Patents Law 1984, "Inventions and utility models for which patent rights are to be granted shall be ones which are novel, creative and of practical use.” this entry get " 0 ” points.

\subsubsection{Compulsory Licensing}

Compulsory licensing requires patentees share the invention with third parties, if a country does not impose compulsory licensing within 3 or 4 years from the date of patent grant or application, it receives a 1/3 value.

According to Section 6 of the Patents Law 1984, the patent administration department under the State Council may, upon application made by any unit or individual that possesses the conditions for exploitation, grant a compulsory license for exploitation of an invention patent or utility model patent. Thus this entry gets “ 0 ” points.

\subsubsection{Revocation of Patents}

Revocation of patents indicates that if a country does not revoke patents for non-working receives a value of 1/3. This entry can get $1 / 3$ point as there's no relevant provision in the Patent law.

As a result, the value of "Restrictions" is " $1 / 3$ ".

\subsection{Enforcement}

\subsubsection{Preliminary Injunctions}

Preliminary injunctions are pre-trial actions that require individuals to set-back an so-called infringement in or-

\footnotetext{
${ }^{13}$ http://www.wipo.int/treaties/en
} 
der to protect the patentee from infringement until a final decision is made in a trial.

Under Article 61 of the Patents Law 2000 (take effect on July $1^{\text {st }}, 2001$ ), "If the patentee or interested party has evidence to prove that another person is committing or is about to commit a patent infringement, which, unless being checked in time, may cause irreparable harm to his lawful rights and interests, he may, before taking legal action, file an application to request that the people's court order to have such act ceased.” This entry gets $1 / 3$ point since 2001 .

\subsubsection{Contributory Infringement}

Contributory infringement means infringement actions that are not caused by themselves but result in infringement by others.

Under Article 130 of the Civil Law 1986 (take effect on Jan. $\left.1^{\text {st }} .1987\right)^{14}$, "If two or more persons jointly infringe upon another person's rights and cause him damage, they shall bear joint liability.” This entry gets 1/3 since 1987.

\subsubsection{Burden-of-Proof}

Burden-of-proof is the imperative on a party in a trial to produce the evidence that will shift the conclusion away from the patentee to the alleged infringer.

Under Article 60 of the Patents Law 1992 (take effect on Jan. $1^{\text {st }}$. 1993),” If a dispute over patent infringement involves an invention patent for the method of manufacturing a new product, the unit or individual manufacturing the same product shall provide evidence to show that the manufacturing method of their own product is different from the patented method." This entry gets 1/3 since 1993.

Finally, the value of "Enforcement" is " $1 / 3$ " from 1987 to 1992, “2/3" from 1993 to 2000, gets the full mark "1" since 2001.

\subsection{Duration of Protection}

According to the Patent Law, the duration of patent right for inventions shall be fifteen years counted from the date of filing since April $1^{\text {st }}$, 1985, and the duration shall be twenty years since Jan. $1^{\text {st }}, 1993$.

\subsection{Results and Discussion}

From the above we can calculate the level of IPP yearly. As shown in Figure 1, the result is quite different from Park's. The source of the error may be either case laws which said no (not available) or the fact that the documentation Park got were not accurate ${ }^{15}$.

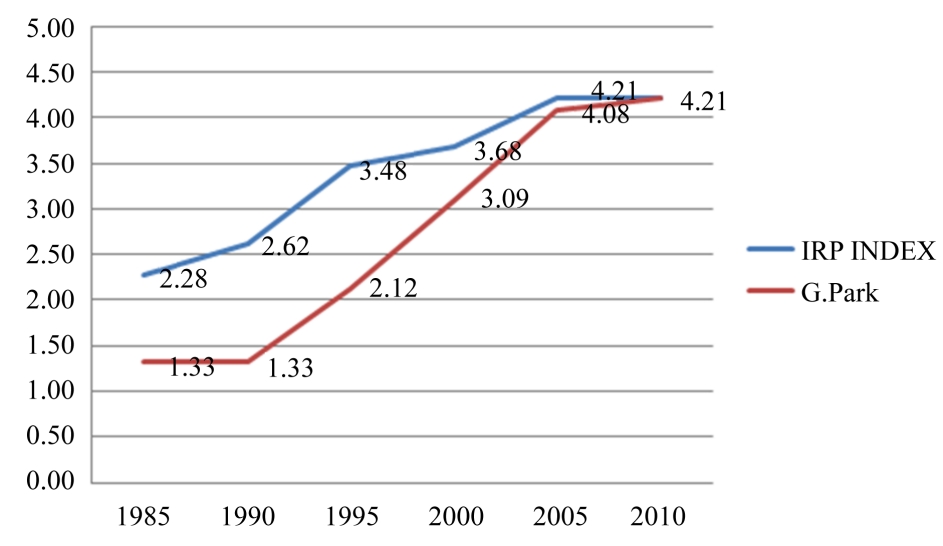

Figure 1. IPP of China based on the method of G. Park.

\footnotetext{
${ }^{14}$ The Civil Law of China (1986).

${ }^{15}$ The author sent an email to Park, and his reply was as follow:

"I only update the index every five years, but I hope to work on 2015 to make the index more timely. The source of the error may be either case laws which said no (not available) or the fact that our documentation here is not up-to-date and current, since we have to translate Chinese laws into English and there is a lag. You should for now use your own scores to represent China until I figure out the difference.”(From Park, March 2014).
} 


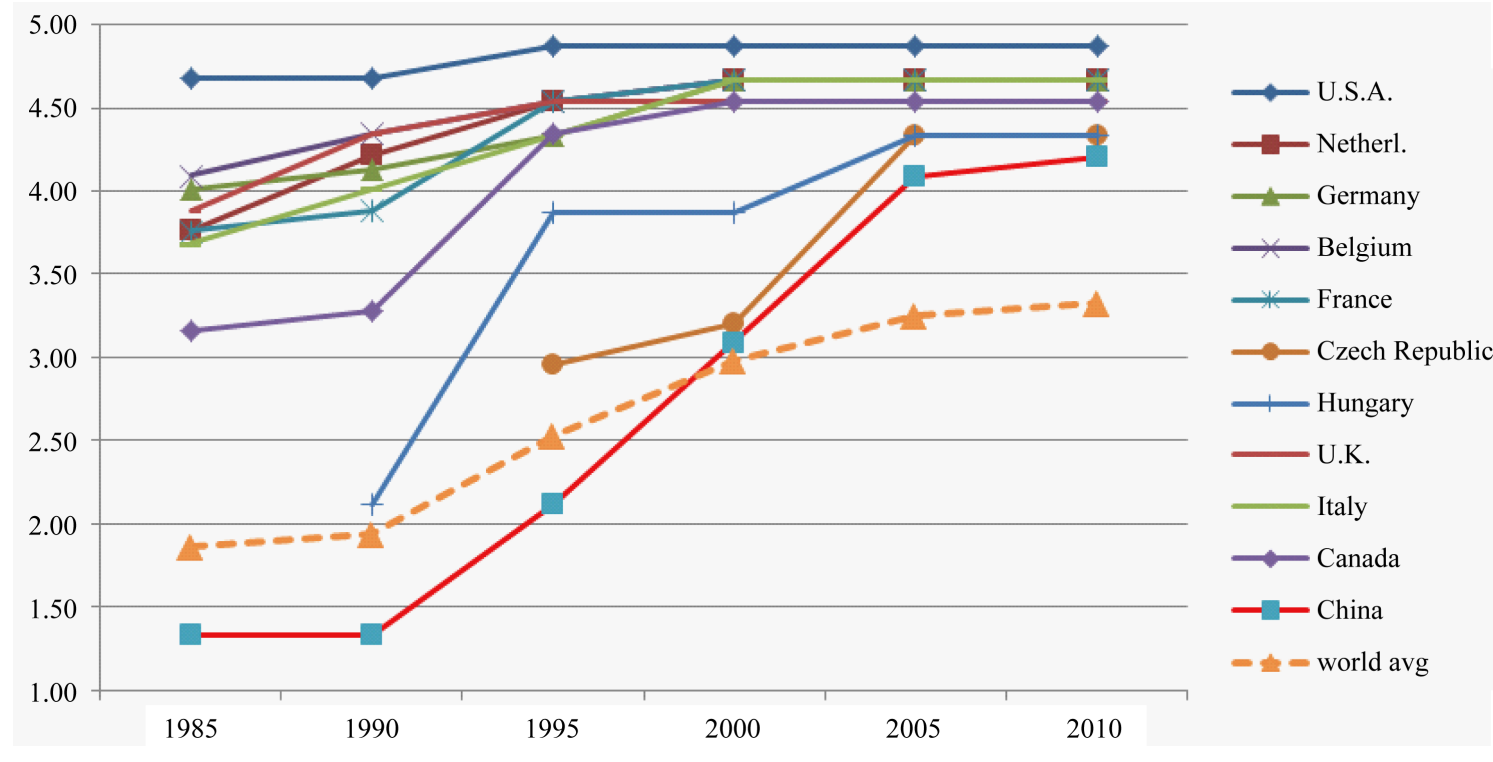

Figure 2. IPP indexes of China and other developed countries. Source: Park’s personal page (2014).

For purposes of comparison we choose some developed countries (top-ten countries ranked by the average in past 25 years). From Figure 2 we can find that the level of IPP in China are growing year by year, and has reached a level close to some developed country, but it does not mean the higher the better, Chinese policy makers should make clear of the fundamental purpose of strengthening intellectual property protection in China is to promote domestic industrial upgrading, encourage innovation, and promote China's economic development, however, China cannot afford this under the existing economic level.

\section{Conclusion}

China's drive to modernization through improving intellectual property protection has been pushed forward by constant efforts to improve formal intellectual property laws and institutions for acquiring, maintaining, and enforcing intellectual property rights. Chinese policymakers and government officials have worked diligently for thirty years in a consistent, unwavering drive to create and improve the country's public intellectual property institutions. It's for sure that both the management and enforcement of IPP in China will make a progress over time.

\section{References}

[1] Beebe, B. (2014) Shanzhai, Sumptuary Law, and Intellectual Property Law in Contemporary China. Vol. 47, New York University, New York, 849-872.

[2] Wang, L. (2004) Intellectual Property Protection in China. International Information \& Library Review, 36, $253-261$. http://dx.doi.org/10.1016/j.iilr.2003.10.007

[3] Godinhoa, M.M. and Ferreirac, V. (2012) Analyzing the Evidence of an IPR Take-Off in China and India. Research Policy, 41, 499-511. http://dx.doi.org/10.1016/j.respol.2011.09.009

[4] Maskus, K., Dougherty, S. and Mertha, A. (2005) Intellectual Property Rights and Economic Development in China. In: Maskus, K.E. and Fink, C., Eds., Intellectual Property and Development: Lessons from Recent Economic Research, Oxford University Press, Oxford, 295-331. http://dx.doi.org/10.1596/0-8213-5772-7

[5] Gould, D. and Gruben, W. (1996) The Role of Intellectual Property Rights in Economic Growth. Journal of Development Economics, 48, 323-350. http://dx.doi.org/10.1016/0304-3878(95)00039-9

[6] Moser, P. (2005) How Do Patent Laws Influence Innovation? Evidence from Nineteenth-Century World's Fairs. American Economic Review, 95, 1214-1236. http://dx.doi.org/10.1257/0002828054825501

[7] Ang, J.S., Cheng, Y. and Wu, C. (2014) Does Enforcement of Intellectual Property Rights Matter in China? Evidence from Financing and Investment Choices in the High-Tech Industry. Review of Economics and Statistics, 96, 332-348. http://dx.doi.org/10.1162/REST_a_00372 
[8] Europe Chamber (2013) Enforcement of Intellectual Property Rights in China. China IPR SME Helpdesk 2013, Beijing, $1-8$.

[9] Yang, D. and Clarke, P. (2005) Globalisation and Intellectual Property in China. Technovation, 25, 545-555. http://dx.doi.org/10.1016/j.technovation.2003.10.008

[10] Xu, C.M. and Shan, X.G. (2008) Constructing of the Index System and Verification for the Intensity of Intellectual Property Protection in China. Studies in Science of Science, 26, 715-723.

[11] Li, W. (2011) The Improvement of China's Intellectual Property Rights Protection. China Collective Economy, 30, 125-126.

[12] Rai, V., Schultz, K. and Funkhouser, E. (2014) International Low Carbon Technology Transfer: Do Intellectual Property Regimes Matter? Global Environmental Change-Human and Policy Dimensions, 24, 60-74. http://dx.doi.org/10.1016/j.gloenvcha.2013.10.004

[13] Bosworth, D.L. (1980) The Transfer of U.S. Technology Abroad. Research Policy, 9, 378-388. http://dx.doi.org/10.1016/0048-7333(80)90033-5

[14] Ferrantino, M.J. (1993) The Effect of Intellectual Property Rights on International Trade and Investment. Weltwirtschaftliches Archiv, 129, 300-331. http://dx.doi.org/10.1007/BF02707699

[15] Rapp, R.T. and Rozek, R.P. (1990) Benefits and Costs of Intellectual Property Protection in Developing Countries. Journal of World Trade, 24, 75-102.

[16] Mansfield, E. (1994) Intellectual Property Protection, Foreign Direct Investment, and Technology Transfer, International Finance Corporation Discussion Paper, World Bank, Washington, DC, 19.

[17] Ginarte, J.C. and Park, W.G. (1997) Determinants of Patent Rights: A Cross-National Study. Research Policy, 26, 283301. http://dx.doi.org/10.1016/S0048-7333(97)00022-X

[18] Park, W.G. (2008) International Patent Protection: 1960-2005. Research Policy, 37, 761-766. 